$\begin{aligned} \text { Molly Brown } & \text { Guilt, guns, girls and ghettos: } \\ \begin{aligned} & \text { Molly Brown is a senior lecturer in } \text { Adjacent futures in selected post- } \\ & \text { English at the University of Pretoria, } \\ & \text { South Africa. She researches on } \\ & \text { children's literature and }\end{aligned} & \text { apartheid fantasies }\end{aligned}$

\title{
Guilt, guns, girls and ghettos: Adjacent futures in selected post-apartheid fantasies
}

Since 1994, a growing number of South African writers of young adult and crossover fiction have experimented with science fiction and fantasy as tools for anticipating potential futures. In this article, three of these works are considered: The Slayer of Shadows by Elana Bregin, Zoo City by Lauren Beukes and The Mall Rats series consisting of Deadlands and Death of a Saint by Lily Herne. The texts are initially briefly contrasted with two texts by authors based in the USA: Lauren St John's The White Giraffe and Sarah Pinsker's "The Trans-dimensional Horsemaster Rabbis of Mpumalanga Province" to show that the three local writers' engagement with the South African present enables them to resist, in varying degrees, prevalent Western tendencies to see positive African futures in terms of either an idealised pre-colonial past or as the result of redemptive agency by external forces. Although almost twenty years separate the Bregin novel from the others, there are clear similarities between them: each is written by a white woman (or women) and each places a young female protagonist within a crumbling, violent and resolutely urban environment. Paradoxically, the future worlds the authors create are at once both profoundly unfamiliar and recognisably South African, perhaps lending credence to Darko Suvin's view that good fantasy gives rise to "cognitive estrangement" (4) by which the reader is freed to explore troubling issues such as guilt and complicity at a safe emotional remove. By foregrounding and contrasting the presentation of divisive contemporary themes such as gender, race, guilt and violence in these novels, it is hoped to establish whether the repressed fears/desires they articulate are in any way indicative of social attitudes to either present experience or imagined futures and whether such attitudes have changed significantly in the twenty years since the first democratic elections. Keywords: Futures literatures, science fiction, South African English Literature, youth literature.

In A Singular Modernity, Fredric Jameson suggests that "radical alternatives, systemic transformations, cannot be theorized or even imagined within the conceptual field governed by the word 'modern'". He then goes on to argue that "what we really need is a wholesale displacement of thematics of modernity by the desire called Utopia" (215). Anyone sharing these views, might have had reason to hope that since Utopian desires indubitably powered the transformation of South African society in 1994, they would subsequently also have encouraged the production of positive visions of the future, not least in the field of young adult literature where the challenges of addressing a non-peer audience tend to promote didacticism and privilege the idea that, as Kay Sambell puts it, the adult author has a responsibility to guide "the reader towards hope" (251). 
Such utopian imaginings can certainly be found in young adult speculative fiction set in South Africa yet intriguingly they often seem to be associated not with an awareness of contemporary African issues, but rather with idealisations of the pre-colonial past. Perhaps unsurprisingly, they are also considerably more common in works written by authors living outside the country where they are ostensibly set. Lauren St John's prize-winning and highly successful "White Giraffe" series, for instance, begins with a novel that introduces readers to Martine, an eleven-yearold English girl who goes to live with her grandmother in South Africa. In this novel and the rest of the series, Martine is depicted as the instrument of salvation for both oppressed Africans and endangered animals. A secondary mixed-race character, Ben, befriends Martine but is stated to be an "outsider" by choice. He has little to do with Martine until she reveals herself as the heroic saviour whose coming has been foretold by African elders. Like Ben, the "good", indigenous Africans in the novels seem instinctively to perceive that they need to subordinate themselves to Martine, whom we are shown depicted as a superior being even in ancient San rock art. Yet while St John may present Martine as predestined to lead South Africa forward to an eco-friendly, egalitarian and utopian future, the critical reader is likely to see this ideal world as uncomfortably reminiscent of the past, since it unquestionably rejects urban modernity and troublingly positions a white British girl as a redemptive force, without showing any awareness that generations of European exploitation may have played a role in building the contemporary Africa that the central character rejects.

Similarly, Sarah Pinsker's “The Transdimensional Horsemaster Rabbis of Mpumalanga Province" takes a grieving Jewish photographer, Yona Heifetz-Perec, into the depths of the country to encounter a lost tribe rooted in a timeless African pastoral dream:

they travelled the length of the valley between steep rock walls. On the other side of the path from the pasture there were crops growing in neat rows: maize, sugarcane, groundnut. The fields gave way to a small orchard, and beyond that, the village itself. Yona counted eighteen small sandstone dwellings. (74-75)

This multi-cultural and often demonstrably unAfrican collage is matched by the hazily-defined characteristics of the villagers, whom we are told look "more Middle Eastern than Ndebele" (75), speak a dialect derived from Syriac or Aramaic and use prayers that "sound like some of the oldest Jewish prayers: the Kaddish, the Shema" (78). More miraculously still, they shift in and out of existence in a collective flickering that suggests to the protagonist that they may be neither African nor even human but alien transdimensional beings. Furthermore, Pinsker's story is compiled as a series of verbal descriptions of imagined photographs and the last of these shows Yona rejecting the grimy streets of urban Kampala, where her partner has been beaten to death, in 
favour of a return to rural simplicity and a future where she is seen "singing with the tribespeople, her face tilted towards the stars" (79).

One cannot help suspecting that for many Western writers, a desirable African future can only be envisaged when it is dissociated from both modernity and indigenous Africans. Bill Ashcroft has observed that "Historicism fixes the indigenous subject at a static moment in the past, a prehistory located under the sign of the primitive; a primal innocence or barbarity. This is the static historical moment from which History, the record of civilization, begins" (117). In the work of St John and Pinsker, a return to this approved stasis becomes a distinguishing marker not only of the African past, but even more disturbingly of its future as well.

In this, both St John and Pinsker reflect a weary afro-pessimism of the type expressed more directly by Paul Theroux, who ends what he claims will be his final travel book with a bitter denunciation of contemporary Africa and a claim that since the future can always be glimpsed in the truthfully-recorded present, the future for Africa does not exist:

My horror interest in the futureless, dystopian, world-gone-wrong, Mad Max Africa of child soldiers, street gangs, reeking slums, refuse heaps, utter despair, misplaced belief, new-age cargo cults, and bungled rescue attempts-this horror interest is rooted in detachment. It is unworthy, no more than idle slightly sickening curiosity over modernity in its most odious form, the sort that technology worsens, by making people lazier and greedier, tantalizing them with visions of the unattainable, driving many of them to be refugees and bludgers in Europe or America. We have bestowed on Africa just enough of the disposable junk of the modern world to create in African cities a junkyard replica of the West, a mirror image of our own failures-but no better than that. (347)

Neither Theroux's contemptuous dismissal of the Africa he encounters nor the easy romanticism of St John or Pinsker is as easily accessible to South African writers. With lives rooted in African modernity and a lived experience of a localised present, they are, unsurprisingly, less willing to accept that the African future ended with the loss of its pre-colonial and pre-industrial past. Nonetheless, the future worlds reflected in recent speculative fiction by white South African writers, in particular, seem almost uniformly anti-utopian or dystopian. (In discussing these categories, I follow Tom Moylan's distinction between anti-utopias in which the worlds created lacks any sites for effective resistance or potential for improvement and dystopias in which protagonists or readers are encouraged to perceive positions from which resistance becomes possible.)

The absence of utopian futures in South African young adult fantasy may also be explicable in terms of Rob McAlear's view that "if the persuasive strategy that governs utopias is 'hope', for dystopias it is 'fear'" (25). For this reason too, McAlear notes that 
dystopia almost invariably locates itself in the "near-future novel" (28), creating worlds no more than a temporal step from the reader's own and thus adjacent enough to now to be responsive to and shaped by contemporary decisions. Four such works of speculative fiction are The Slayer of Shadows (1996) by Elana Bregin, Zoo City (2010) by Lauren Beukes and "The Mall Rats" series consisting at the time of writing of Deadlands (2012) and Death of a Saint (2012) by Sarah and Savannah Lotz writing as Lily Herne. These diverge sharply from the texts by St John and Pinsker in that they each place a young female protagonist within a crumbling and violent urban environment rather than an idealised pastoral one. Intriguingly, the gun-ridden ghettos the authors create are at once both profoundly unfamiliar and recognisably South African in ways that may support Darko Suvin's view that the value of fantasy lies in its ability to bring about an experience of "cognitive estrangement" (4) by which the reader is freed to explore current issues at a safe emotional remove.

The Slayer of Shadows, published only two years after South Africa's first democratic election, is a novel usually shelved with young adult books though some critics have found it too disturbing to be suitable for this age group. In it Elana Bregin describes a young girl whose name we are told "means Sorrow" (3). The girl is saved from a wretched existence in an unidentified shanty town known only as the Jungle by Zach, a compassionate teacher and the slayer of shadows to whom the title refers. Zach stands in continual opposition to both the hopeless poverty and despair of the Jungle ghetto and the ruthless "Jakkals", gangsters who prey relentlessly on its suffering inhabitants. In the course of the novel, Zach's wife and unborn baby are savagely slaughtered and "Sorrow", whom he has renamed Marinda, is raped and impregnated by two unknown men whom she suspects of operating on orders from the "Jakkals". Marinda, who sees ghosts and can talk to cockroaches, accesses what might be seen as the traditionally feminine powers of witchcraft to draw a circle of protection about their home. At first, she seems to do this successfully, but the menstrual blood with which she anoints Zach's door is soon overlaid by the blood of his slaughtered infant, metaphorically emphasizing that nurture and regeneration can never be possible in this anti-utopian future. Torn apart by their separate and all-consuming experiences of trauma, Zach and Marinda withdraw into their separate griefs. Finally, however, Marinda goes in search of Zach and they are reunited beyond the Jungle, in an unnamed and perhaps atemporal liminal space where there are clean shores and a river flows into the sea. Here Marinda comes to believe that the child born of her rape is, in some spiritual sense, also Zach's child: "'He has your spirit in him too,' I continued softly. 'Don't ask me to explain it. He is the child that should have been conceived between us'" (149). The final paragraph of the novel then presents the unborn child laying violent claim to the years ahead. Marinda says:

I look across the future sometimes. And I see my son there, striding tall and dark and invincible through the shadows of this world. I think-I know-that the 
Jungle has not seen the last of him. When he returns there it will be with the avenging might of angels on his side. And the Jakkals shall have cause to rue his sting. (152)

Even the most superficial analysis of this novel soon shows that The Slayer of Shadows is rooted in the overwhelming climate of fear that dominated most sectors of the white community in the immediate aftermath of the 1994 election. The Jungle may never be overtly identified with South Africa, but it is clear that the novel is set after a successful but disillusioning freedom struggle. Marinda states:

That war was the great Freedom Struggle, against our racist oppressors. It started as a just campaign. But soon the power-greedy-hijacked the Cause for their own ends. Few in the Jungle feel any sense of liberation now. The Struggle has been over for a long time. Yet we are less free than we ever were. (9)

Given this context, the bright fair hair which distinguishes Zach so oddly from the rest of the characters seems disturbingly indicative of an unspoken belief in the merits of fair-haired colonizers who, again like Zach, once brought brick schoolrooms to the jungles of darkest Africa. Seen in this light, Marinda also takes on aspects of Shakespeare's Miranda, who in The Tempest, needs to be protected from the savage indigene, Caliban, by the wise and paternal exile, Prospero. Marinda, like Miranda and many characters in contemporary young adult anti-utopias, is cast as an innocent and helpless victim, even though the child she carries is presented as an avenging avatar of salvation. In this way, Bregin's novel illustrates Kay Sembell's view that "the child as an emblem of hope for the future" and "the child as helpless victim are often held in acute tension in dystopian writing for young readers" (252).

Lily Herne's Deadlands and Death of a Saint, published almost twenty years later, reveal similar tensions while exploring a near-future in which South Africa has been struck by a zombie plague, demonstrating that local youth literature is not immune to global commodity culture even if the South African context does give surprising twists to the presentation of the living-dead. In Herne's texts, the survivors of the zombie apocalypse huddle in walled enclaves and are subject to mysterious Guardians, who are able to control the zombies and provide the docile remnants of humanity with their basic needs. In return, they exact an annual tribute of teenagers. Seventeenyear-old Lele de la Fontein is chosen as one of these tributes, but manages to escape from the wagon taking her out of her enclave and join a group of teenagers calling themselves the Mall Rats. Mysteriously, the members of the group do not attract the attention of any but the newest zombies or "Rotters". Because of this, they are able to leave the enclave and bring back black-market goods from the Ratanga Junction mall. The novels do not foreground racial divisions as clearly as The Slayer of Shadows does in that Lele's race is never discussed and neither is that of Ash, the boy to whom she is strongly attracted. The remaining Mall Rats also seem consciously conceived to 
establish a multi-ethnic ethos: Saint is a lesbian from Botswana, whose lover, Ripley, has been taken by the Guardians, and Ginger is a red-headed British boy who was visiting South Africa for the Football World Cup when the plague struck.

The world which surrounds the protagonists is an indubitably hostile one and yet are clear and disturbing parallels between life in the besieged enclaves and life in the privileged security villages that have become such an essential part of the current South African urban landscape. This is made very clear when the Mall Rats leave Cape Town in the second novel and spend some time in what was once a golf estate near Knysna where Ginger and Megan, whose father is in charge of this particular enclave, have a particularly suggestive conversation:

'How did what's-his-name-Father-have time to build these walls if you didn't have any Guardians protecting you?' Ginger asks.

'He didn't,' Megan says. 'It was already here. He just took it over.'

'So what was this place?'

'A golf estate. The whole thing was fenced already.'

'Oh, that was lucky, innit.'

'Father's always saying that South Africa must be one of the best countries in the world for surviving a zombie apocalypse.' Megan says seriously, 'It's full of security estates and high fences.' (173)

Similar echoes of the present are found when a well-armed, Afrikaans-speaking farming couple from the Free State first shoot at the teenagers and then offer them a meal and a bed in a self-sufficient farmhouse, which comes close to parodying right-wing, survivalist ideals. Outside the little house with its well-stocked larder, a group of Rotters are staked out like macabre scarecrows to act as an organic burglar alarm or early warning system. Disturbed by this, Ash says to Lele, after accepting a food parcel from their hosts, "It's a good job we judge people on how they treat the living, and not on how they treat the dead" (291). One cannot help feeling though that on some disturbing and possibly unacknowledged level, the shambling and horrifying Rotters in their ragged clothes may be operating as nightmarish analogues for the threatening, poverty-stricken crowds that wealthy South Africans of all races determinedly continue to Other and marginalize.

Thus while Herne's work may avoid the nascent nostalgia of Bregin's novel, it is as surely rooted in its own temporal environment, offering support for Marius Conken's (221) assertion that dystopia is "umbilically linked to the present from which it acquires negative elements necessary for the construction of certain hyperboles of evil". Significantly, the so-called Resurrectionists, who laud the Guardians from whom Lele has escaped, look back on life before the zombie plague with little regret, handing out a pamphlet that reads: 
Do you remember the terrible days of hijackings. Murder? Domestic Violence? Robbery? Et cetera? Yes? Then join us in celebrating our Saviours Who Have Set Us Free. Become ReBorn with a view to a glorious ReAnimation. (17)

Furthermore, Lele's school history text book claims that "[b]efore the War, South Africa was a mess of violence, extreme poverty, HIV infection, incest, child abuse, terrorism and murder" (41) and the anti-zombie resistance movement, which regularly bombs civilian targets and is rejected by the central characters, is also known as the ANZ, which Lele herself tellingly confuses with the ANC (64).

Like Marinda then, Lele is portrayed as an innocent fighting for survival in a hostile urban environment in which violence is an everyday occurrence. However, unlike Marinda, Lele has no bright-haired adult or unborn son to offer her even an illusion of protection. Her weak father is powerless against the Guardians, whose predatory actions mock their title and Hester, who trains the Mall Rats in martial arts and whom we are told in a nod to celebrity culture, is way cooler than Angelina Jolie (146), slowly succumbs to cancer. Lele's fighting skills may grant her more personal agency than Marinda is ever allowed, but their acquisition also ensures that the books position violence as the only appropriate response to threats. In this way, Herne's work conforms to what Sambell identifies as another common paradigm of children's dystopia in that it creates "a sharp distinction between corrupt adulthood and innocent childhood" (251). Once such a dichotomy is established, authors like Herne find themselves trapped in a situation in which either the survival of the young protagonist begins to seem wildly improbable or they have to find ways of valorising aggression and cunning in these characters while simultaneously condemning it in those ranged against them.

Intriguingly, at the end of Deadlands, Herne (317) seems to suggest that this impasse may be resolved in a more nuanced way when Lele discovers that she may have more in common with the Rotters whom she opposes than the human teenagers with whom she identifies. When Lele is injured, she finds that she has silver fibres embedded in her flesh. The implications of this leave her reeling as she says:

I moved like an automaton [...] horror, nausea and disbelief melding as the last piece of the puzzle fell into place. No wonder I never had any lasting injuries whenever I was hurt. No wonder the Rotters didn't try to attack me. Why would they attack one of their own? (317)

To date, however, this extraordinary revelation has yet to be fully developed. Instead Herne seems to have drawn back from the brink of epiphany and the second book in the series degenerates into a sequence of set battles against opponents who, whether they are Guardians or Rotters, are once again simply and ineluctably defined as Other. Violence and segregation thus saturate both Herne and Bregin's works, while the girls 
at their centres are each presented as essentially guiltless and without responsibility for the hostile environments in which they struggle in different ways for survival.

Lauren Beukes's Zoo City, first published in 2010 and usually marketed as adult speculative fiction, but which has considerable appeal as a cross-over text, has much in common with the novels previously discussed, perhaps indicating the truth of Frederick Pohl's claim that adult and children's science fiction tackle such similar dystopian themes that there is little to differentiate them (111). What is noteworthy though is that despite these similarities, Zoo City startlingly reverses the polarities of segregation found in both Bregin and Herne. Its young female protagonist, Zinzi December, lives in Hillbrow, a crumbling inner-city ghetto, but unlike Marinda or Lele, she is presented as guilt-ridden rather than innocent and threatening rather than threatened. Marinda looks to Zach to rescue her from the amoral chaos of the Jungle and Lele fights her way from one besieged enclave of relative privilege to another. Zinzi, on the other hand, seems entirely at home on hostile streets where gunfire is so much part of the nocturnal soundscape that she is able to nonchalantly compare it to "cicadas in the countryside" or "microwave popcorn" (49). The reader is initially told that Zinzi makes a living from her mashavi or gift for finding lost things, but then soon learns that she also creates internet scams on behalf of a criminal cartel which controls her drug debt. She has chosen to live in Elysium Heights, an ironically named tenement, finding "something comforting about the barbed wire and broken windows, the way all the buildings connected by officially constructed walkways or improvised bridges to form one sprawling ghetto warren" that reminds her "reassuringly" of prison (50). Furthermore, Beukes soon reveals that Zinzi has served time following the death of her brother in an episode of drug-related violence, which it is inferred came about as a direct result of her addiction.

While Zinzi's Johannesburg is in many ways indistinguishable from its present day counterpart, it is made adjacent to the reader's world by the fact that in it anyone responsible for the death of another finds themselves aposymbiotically twinned with an animal. Being parted from these creatures causes their human partners intense pain and should such an animal die, the human paired with it vanishes in a black cloud popularly known as the "Undertow" and tellingly described by a fictional Jungian analyst within the novel as "shadow-self absorption" (157-58). These animal familiars are sometimes compared to the daemons in Philip Pullman's best-selling His Dark Materials trilogy, but are considerably more corporeal and seem to be emblematic of guilt rather than indicative of character or the possession of a soul. A policewoman states this quite clearly within the opening pages of the novel, saying to Zinzi:

'All I'm saying is that you've murdered before.'

'The court said accessory to.'

'That's not what the thing on your back says.'

'He's a Sloth.'

'He's guilt.' (24, italics original) 
The direct result of being "animalled" is that Zinzi also finds herself socially marginalized since, as an anonymous internet user declares: "Get it together, people, apos aren't human. It's right there in the name. Zoos. Animalled. Aposymbiots. Whatever PC term is flavour of the week. As in not human. As in short for 'apocalypse" (64).

As the novel proceeds, Zinzi is drawn into searching for a missing teenage singer, Song, who together with her twin brother, $\mathrm{S}^{\prime}$ bu is part of a lucrative musical duo controlled by a reclusive impresario named Odi Huron. When Zinzi approaches the gated community in which Huron lives, she, unlike either Marinda or Lele, views its walls primarily from the outside looking in, saying with characteristically ribald frankness: "The grassy verges on the pavement are more manicured than a porn star's topiary, running up to ten-metre-high walls topped with electric fencing. Anything could happen behind those walls and you wouldn't know a thing. Maybe that's the point." (68) Her observation is soon seen to be prophetic as Huron is revealed to be the kingpin of a gang that is murdering Zoos for muti (magical) purposes. As a result of his activities, he himself is twinned with a man-eating white crocodile to which he feeds his enemies, possibly suggesting that unacknowledged guilt perpetuates both violence and the denial of humanity to others. Certainly, by the end of the book, Beukes allows Zinzi, who openly accepts her complicity in the death of her brother, and her lover, Benoit, who broods obsessively on the wife and children he abandoned to come to South Africa, to metamorphose into unlikely symbols of redemption. At the same time, the utterly amoral Huron's palatial home is revealed as no safe haven but a façade for a charnel house of greed and corruption.

Chantelle Gray van Heeden has suggested that Huron's crocodile may be "a notso-subtle reference to P. W. Botha" (s.p.) and while this may be tendentious, it is certainly true that the underlying tenor of Beukes's novel seems to speak directly to white South African readers in its assertion that guns cannot be contained by walls or ghettos and that segregation breeds rather than restrains the violence that the antiutopian visions of Bregin and Herne share.

Significantly, at the end of Zoo City, Zinzi leaves Johannesburg and the injured Benoît to go in search of her lover's wife and children who have recently made contact from a refugee camp in Kigali. By this act of unselfish generosity, she is freed to confront her African identity for the first time, admitting as she plans her itinerary that the place names "sound like new worlds" since she has "only ever travelled to Europe" (309). In a sense then, Beukes's heroine contradicts Roger Schlobin's (14) assertion that "the death of I is central to dystopia" in that she shows that while individual identity may be and often is dispersed, annulled or objectified by those in pursuit of power, it may well also be that it can only be found in the voluntary surrender of self-interest. In the novel's final paragraph, Zinzi lists the names of Benoît's wife and children, symbolically according each of these unknown Others identity and value, before saying paradoxically: 
It's going to be awkward. It's going to be the best thing I've done with my miserable life.

And after that? Maybe I'll get lost for a while. (309)

The novel thus ends with an escape into what Hadomi (cited in Podzik 193) classifies as "intopia" rather than utopia, a state in which the central character comes to define his or her utopian quest in subjective and relativistic terms as a search for an alternative inner reality rather than a more general socio-economic one.

The validity of such individual reclusion from the socio-political is obviously open to question and may readily be dismissed as stemming from the disproportionate value placed on individualism by contemporary proponents of neoliberalism, yet it is easy to see how it also reflects a growing South African disillusionment with power structures that continue to efface the needs and voices of those marginalized by either ethnicity or gender. Ultimately, Beukes seems to suggest that Zinzi, a poor female whose cultural identity seems to be at odds with her ethnicity, may have no choice but to abandon any dream of redemption beyond the personal and intangible hope implied by the novel's final lines.

The three works at the heart of this article can thus be seen as presenting adjacent futures locked into extensions of far too familiar South African paradigms of violence, corruption, segregation and crumbling infrastructure, all of which seem to have changed only marginally in the twenty years since the country's transition to democracy. It is important to remember, however, that the novels also reflect widespread contemporary experience that is by no means unique to Africa; as Mike Davis argues, we all have to come to terms with the fact that "[i]nstead of cities of light soaring towards heaven, much of the twenty-first-century urban world squats in squalor, surrounded by pollution excrement and decay" (19). In this context, perhaps it is too much to hope that writers anywhere should be able to move beyond guns, ghettos and the violence and division these exemplify to articulate either new ways of seeing the contested spaces of the past or new models of identity linked to a positive view of changed and changing societies.

Yet I would suggest that it is significant that Zoo City, which is the only one of the novels discussed in this paper to acknowledge its central character's complicity in and shared responsibility for the dystopian environment in which she finds herself, is also the only one to resist closure and thus allow for the possibility of hope, even if this is situated beyond the horizon of the text. By placing this hope outside the horizon of existing social constructions, Beukes also ensures that the glimmer of possibility that her novel holds out differs radically both from the closed temporalities of hope associated with earlier political emancipation and the reactionary violence Bregin's heroine so eagerly anticipates. In Zoo City, futurity and hope thus lose a political horizon and become related instead to openness and contingency. 
Similarly, I would also argue that by representing tactics of resistance which are not simply mirror images of tactics of oppression, Zinzi December rejects masculine paradigms of authority in favour of what may be seen as traditionally feminine values involving nurturing and renunciation. Ironically, it is by accepting her own powerlessness within the dominant narratives of her violent, acquisitive and divided society that Zinzi finally allows the reader a fleeting glimpse of a world at odds with the thematics of modernity. In placing the needs of Benoit's utterly disempowered and excluded family before her own, Beukes's central character reflects activist Breyten Breytenbach's view that our capacity for imagining liberation —and liberating our imagination—will at least in part be measured by the extent to which we functionally recognise and receive the dignified human in the other.

I believe we are doomed (programmed, you might say) to strive for a certain human dignity, to extol a given tenderness of life-and these can be measured by our capacity for recognising in the other what we share, and by our willingness to become other.

I believe this is how, in all creole honesty, we may fabricate the commons. (33)

Zinzi's final actions are thus neither simply quixotic nor representative of a withdrawal into "intopia" that is also indicative of a flinching away from community. Instead Beukes ensures that Zinzi's actions foreground the traditional values of $u b u n t u$, the belief that societies and individuals are defined by and made to endure by their respect for others. In this way Zoo City is not simply content with making the future look like the past; instead it interrogates the girls, guns and ghettos characteristic of so many of the futures depicted in South African popular fiction for young adults while also daring to acknowledge the guilt such works often exclude. Finally, it is this acknowledgement that enables a moment of creative dystopia, through which both characters and readers are permitted to glimpse transforming future possibilities as they access what Fredric Jameson, in Archaeologies of the Future: The Desire Called Utopia and Other Science Fictions, has called speculative fiction's "structurally unique capacity" to allow us to apprehend "the present as history" (288).

\section{Works Cited}

Ashcroft, Bill. Post-Colonial Transformation. London: Routledge, 2001.

Barrter, Martha. Ed. The Utopian Fantastic, Westport: Praeger, 2004.

Beukes, Lauren. Zoo City. Auckland Park: Jacana, 2010.

Bregin, Elana. The Slayer of Shadows. Durban: Gecko, 1996.

Breytenbach, Breyten. "The Future of Our Dreaming". The Mail \& Guardian (28 March-3 April 2014), 33.

Conkin, Marius. "Revisiting Fantastic Dystopias". Caietele Echinox 23 (2012) 216-23.

Davis, Mike. Planet of Slums. London: Verso, 2006.

Herne, Lily. Death of a Saint. Johannesburg: Penguin, 2012. 
—. Deadlands. Johannesburg: Penguin, 2012.

Jameson, Fredric. A Singular Modernity. London: Verso, 2002.

—. Archaeologies of the Future: The Desire Called Utopia and Other Science Fictions. New York: Verso, 2005.

McAlear, Rob. "The Value of Fear: Towards a Rhetorical Mode”. Interdisciplinary Humanities 27.2 (2010): $24-42$.

Moylan, Tom. Scraps of the Untainted Sky: Science Fiction, Utopia, Dystopia. Boulder, CO: WestviewPerseus, 2000.

Pinsker, Sarah. "The Transdimensional Horsemaster Rabbis of Mpumalanga Province”. Asimov's Science Fiction 38.2 (2014), 68-79.

Pordzik, Ralph. "Nationalism, Cross-Culturalism, and Utopian Vision in South African Utopian and Dystopian Writing 1972-92". Research in African Literatures 32.3 (2001): 177-97.

Pullman, Philip. Northern Lights. London: Scholastic, 1998.

—. The Subtle Knife. London: Scholastic, 1998.

—. The Amber Spyglass. London: Scholastic, 2001.

Sambell, Kaye. "Carnivalizing the Future: A New Approach to Theorizing Childhood and Adulthood in Science Fiction for Young Readers". The Lion and the Unicorn 28.2 (2004): 247-67.

Schlobin, Roger C. "Dark Shadows and Bright Lights: Generators and Maintainers of Utopias and Dystopias". The Utopian Fantastic. Ed. Martha Barrter. Westport: Praeger, 2004. 11-16.

Shakespeare, William. The Tempest. Eds. Virginia Mason Vaughn and Alden T. Vaughn. The Arden Shakespeare. Third Series. London: Thomson Learning, 1991.

St John, Lauren. The White Giraffe. London: Orion 2006.

—. Dolphin Song. London: Orion, 2007.

—. The Last Leopard. London: Orion, 2008.

Suvin, Darko. Metamorphosis of Science Fiction: On the Poetics and History of a Literary Genre. New Haven, CT: Yale UP, 1979.

Theroux, Paul. The Last Train to Zama Verde: Overland from Cape Town to Angola. London: Hamish Hamilton (Penguin), 2013.

Van Heerden, Chantelle Gray. "Fabulation as Mediation: Review of Lauren Beukes's Zoo City". SLiP (Stellenbosch Literary Project). 2011. 19 Jun. 2013. 